NBER WORKING PAPER SERIES

INVESTING IN OUR YOUNG PEOPLE

Flavio Cunha

James J. Heckman

Working Paper 16201

http://www.nber.org/papers/w16201

\author{
NATIONAL BUREAU OF ECONOMIC RESEARCH \\ 1050 Massachusetts Avenue \\ Cambridge, MA 02138 \\ July 2010
}

This paper was supported by grants from the National Science Foundation (SES-0241858, SES-0099195, SES-0452089, SES-0752699); the National Institute of Child Health and Human Development (R01HD43411); the J. B. and M. K. Pritzker Foundation; the Susan Buffett Foundation;the American Bar Foundation; the Children's Initiative, a project of the Pritzker Family Foundation at the Harris School of Public Policy Studies at the University of Chicago; and PAES, supported by the Pew Foundation. The views expressed herein are those of the authors and do not necessarily reflect the views of the National Bureau of Economic Research.

NBER working papers are circulated for discussion and comment purposes. They have not been peerreviewed or been subject to the review by the NBER Board of Directors that accompanies official NBER publications.

(C) 2010 by Flavio Cunha and James J. Heckman. All rights reserved. Short sections of text, not to exceed two paragraphs, may be quoted without explicit permission provided that full credit, including (C) notice, is given to the source. 
Investing in Our Young People

Flavio Cunha and James J. Heckman

NBER Working Paper No. 16201

July 2010

JEL No. D91,J13,J24

\begin{abstract}
$\underline{\text { ABSTRACT }}$
This paper reviews the recent literature on the production of skills of young persons. The literature features the multiplicity of skills that explain success in a variety of life outcomes. Noncognitive skills play a fundamental role in successful lives. The dynamics of skill formation reveal the interplay of cognitive and noncognitive skills, and the presence of critical and sensitive periods in the life-cycle. We discuss the optimal timing of investment over the life-cycle.
\end{abstract}

Flavio Cunha

Department of Economics

University of Pennsylvania

160 McNeil Building

3718 Locust Walk

Philadelphia, PA 19104-6297

and NBER

fcunha@sas.upenn.edu

James J. Heckman

Department of Economics

The University of Chicago

1126 E. 59th Street

Chicago, IL 60637

and University College Dublin and IZA

and also NBER

jjh@uchicago.edu 


\title{
Investing in Our Young People
}

\author{
Flavio Cunha \\ University of Pennsylvania \\ James Heckman \\ University of Chicago \\ Geary Institute, University College Dublin \\ and American Bar Foundation
}

Keywords: skill formation, cognitive skills, noncognitive skills, technology of skill formation, investment in children

JEL Codes: J13, J24, D91

\begin{abstract}
This paper reviews the recent literature on the production of skills of young persons. The literature features the multiplicity of skills that explain success in a variety of life outcomes. Noncognitive skills play a fundamental role in successful lives. The dynamics of skill formation reveal the interplay of cognitive and noncognitive skills, and the presence of critical and sensitive periods in the life-cycle. We discuss the optimal timing of investment over the life-cycle.
\end{abstract}

\section{Introduction}

It is well documented that people have diverse abilities, that these abilities account for a substantial portion of the variation across people in socioeconomic success, and that persistent and substantial ability gaps across children from various socioeconomic groups emerge before they start school. The family plays a powerful role in shaping these abilities through genetics and parental investments and through choice of child environments. A variety of intervention studies indicate that ability gaps in children from different socioeconomic groups can be reduced if remediation is attempted at early ages. The remediation efforts that appear to be most effective are those that sup-

This paper was supported by grants from the National Science Foundation (SES-0241858, SES-0099195, SES0452089, SES-0752699); the National Institute of Child Health and Human Development(R01HD43411); the J. B. and M. K. Pritzker Foundation; the Susan Buffett Foundation;the American Bar Foundation; the Childrens Initiative, a project of the Pritzker Family Foundation at the Harris School of Public Policy Studies at the University of Chicago; and PAES, supported by the Pew Foundation. Contact: Department of Economics, University of Chicago, 1126 E. 59th Street, Chicago IL 60637. Tel: 773-702-0634; fax: 773-702-8490. Email: jjh@uchicago.edu. 
plement family environments for disadvantaged children. Cunha, Heckman, Lochner, \& Masterov (2006), henceforth CHLM, present a comprehensive survey and discussion of this literature.

This paper uses a simple economic model of skill formation to organize this and other evidence summarized here and the findings of related literatures in psychology, education, and neuroscience. The existing economic models of child development treat childhood as a single period (see, e.g., Becker \& Tomes, 1986; Aiyagari, Greenwood, \& Seshadri, 2002; Benabou, 2002). The implicit assumption in this approach is that inputs into the production of skills at different stages of childhood are perfect substitutes. Instead, we argue that to account for a large body of evidence, it is important to build a model of skill formation with multiple stages of childhood, where inputs at different stages are complements and where there is self-productivity of investment. In addition, to rationalize the evidence, it is important to recognize three distinct credit constraints operating on the family and its children. The first constraint is the inability of a child to choose its parents. This is the fundamental constraint imposed by the accident of birth. Second is the inability of parents to borrow against their children's future income to finance investments in them. The third constraint is the inability of parents to borrow against their own income to finance investments in their children.

This paper summarizes findings from the recent literature on child development and presents a model that explains them. A model that is faithful to the evidence must recognize that (a) parental influences are key factors governing child development; (b) early childhood investments must be distinguished from late childhood investments; (c) an equity-efficiency trade-off exists for late investments, but not for early investments; (d) abilities are created, not solely inherited, and are multiple in variety; (e) the traditional ability-skills dichotomy is misleading because both skills and abilities are created; and (f) the "nature versus nurture" distinction is obsolete. These insights change the way we interpret evidence and design policy about investing in children. Point (a) is emphasized in many papers. Point (b) is ignored in models that consider only one period of childhood investment. Points (c), (d), and (e) have received scant attention in the formal literature on child investment. Point (f) is ignored in the literature that partitions the variance of child outcomes into components due to nature and components due to nurture.

\section{Observations About Human Diversity and Human Development and Some Facts Our Model Explains}

Any analysis of human development must reckon with three empirically well-established observations about ability. The first observation is that ability matters. A large number of empirical studies document that cognitive ability is a powerful determinant of wages, schooling, participation in crime, and success in many aspects of social and economic life. The frenzy generated by Richard J. Herrnstein and Charles A. Murray's book, The Bell Curve, because of its claims of genetic determinism, obscured its real message, which is that cognitive ability is an important predictor of socioeconomic success. (See, e.g., Heckman, 1995, and Murnane, Willett, \& Levy, 1995.)

A second observation, more recently established, is that abilities are multiple in nature. 
Noncognitive abilities (perseverance, motivation, time preference, risk aversion, self-esteem, selfcontrol, preference for leisure) have direct effects on wages (controlling for schooling), schooling, teenage pregnancy, smoking, crime, performance on achievement tests, and many other aspects of social and economic life (Borghans, Duckworth, Heckman, \& ter Weel, 2008; Bowles, Gintis, \& Osborne, 2001; Heckman, Stixrud, \& Urzua, 2006).

The third observation is that the nature versus nurture distinction is obsolete. The modern literature on epigenetic expression teaches us that the sharp distinction between acquired skills and ability featured in the early human capital literature is not tenable (see, e.g., Gluckman \& Hanson, 2005, and Rutter, 2006). ${ }^{1}$ Additive "nature" and "nurture" models, while traditional and still used in many studies of heritability and family influence, mischaracterize how ability is manifested. Abilities are produced, and gene expression is governed, by environmental conditions (Rutter, 2006). Measured abilities are susceptible to environmental influences, including in utero experiences, and also have genetic components. These factors interact to produce behaviors and abilities that have both a genetic and an acquired character. ${ }^{2,3}$ Genes and environment cannot be meaningfully parsed by traditional linear models that assign variance to each component.

Taking these observations as established, we develop a simple economic model to explain the following six facts from the recent empirical literature. First, ability gaps between individuals and across socioeconomic groups open up at early ages, for both cognitive and noncognitive skills. See Figure 1 for a prototypical figure which graphs a cognitive test score by age of child by socioeconomic status of the family. ${ }^{4}$ CHLM present many additional graphs of child cognitive and noncognitive skills by age showing early divergence and then near parallelism during school-going years across children with parents of different socioeconomic status. Levels of child skills are highly correlated with family background factors like parental education and maternal ability, which, when statistically controlled for, largely eliminate these gaps (see Carneiro \& Heckman, 2003, and CHLM). Experimental interventions with long-term follow-up confirm that changing the resources available to disadvantaged children improves their adult outcomes. See the studies surveyed in CHLM or Blau \& Currie (2006). Schooling quality and school resources have relatively small effects on ability deficits and have little effect on test scores by age across children from different socioeconomic groups, as displayed in Figure 1 and related graphs (see Heckman, Larenas, \& Urzua, 2004, and Raudenbush, 2006).

Second, in both animal and human species, there is compelling evidence of critical and sensitive periods in the development of the child. Some skills or traits are more readily acquired at certain stages of childhood than other traits (see the evidence summarized in Knudsen, Heckman,

\footnotetext{
${ }^{1}$ For example, Becker (1993, pp. 99-100) contrasts the implications for the earnings distribution of ability models of earnings and human capital models, claiming the latter are more consistent with the empirical evidence on earnings. The implicit assumption in his analysis and the literature it spawned is that ability is determined by "nature", i.e., is genetic, and outside the influence of family investment strategies.

${ }^{2}$ There is some evidence that gene expression affected by environment is heritable (see Rutter, 2006).

${ }^{3}$ Some recent evidence on gene-environment interactions resulting from child maltreatment is presented in Caspi, McClay, Moffitt, Mill, Martin, Craig et al. (2002). Rutter (2006) surveys this evidence.

${ }^{4}$ Permanent income is the measure of socioeconomic status in this figure. See CHLM for the source of this figure and the precise definition of permanent income.
} 
Figure 1. Children of NLSY: Average percentile rank on PIAT Math score, by income quartile.*

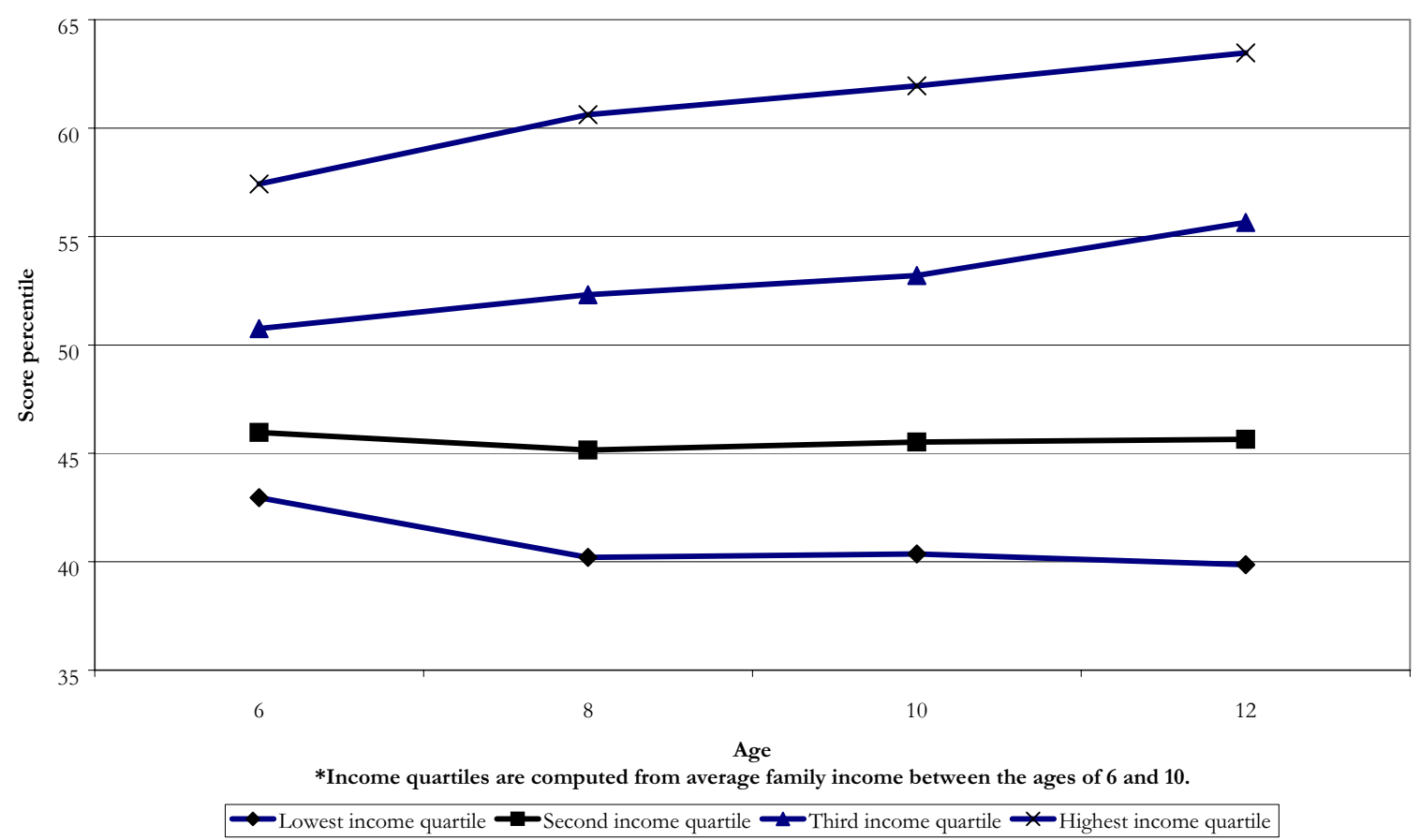

Cameron, \& Shonkoff, 2006). For example, on average, if a second language is learned before age 12, the child speaks it without an accent (Newport, 1990). If syntax and grammar are not acquired early on, they appear to be very difficult to learn later on in life (Pinker, 1994). A child born with a cataract will be blind if the cataract is not removed within the first year of life.

Different types of abilities appear to be manipulable at different ages. IQ scores become stable by age 10 or so, suggesting a sensitive period for their formation below age 10. (See Hopkins \& Bracht, 1975.) There is evidence that adolescent interventions can affect noncognitive skills (see CHLM). This evidence is supported by the neuroscience that establishes the malleability of the prefrontal cortex into the early 20s (Dahl, 2004). This is the region of the brain that governs emotion and self-regulation.

On average, the later remediation is given to a disadvantaged child, the less effective it is. A study by O'Connor, Rutter, Beckett, Keaveney, Kreppner, \& the English and Romanian Adoptees Study Team (2000) of adopted Romanian infants reared in severely deprived orphanage environments before being adopted supports this claim. The later the Romanian orphan was rescued from the social, emotional and cognitive isolation of the orphanage, the lower was his or her cognitive performance at age 6 . Classroom remediation programs designed to combat early cognitive deficits have a poor track record.

At historically funded levels, public job training programs and adult literacy and educational programs, like the GED, that attempt to remediate years of educational and emotional neglect among disadvantaged individuals have a low economic return and produce meager effects for most persons. A substantial body of evidence suggests that returns to adolescent education for the most 
disadvantaged and less able are lower than the returns for the more advantaged (Meghir \& Palme, 2001; Carneiro \& Heckman, 2003, and the evidence they cite; Carneiro, Heckman, \& Vytlacil, 2006).

The available evidence suggests that for many skills and abilities, later remediation for early disadvantage to achieve a given level of adult performance may be possible, but is much more costly than early remediation (Cunha \& Heckman, 2007). The economic returns to job training, high school graduation, and college attendance are lower for less able persons. (See Carneiro \& Heckman, 2003.)

Third, despite the low returns to interventions targeted toward disadvantaged adolescents, the empirical literature shows high economic returns for remedial investments in young disadvantaged children (see Barnett (2004), the evidence in CHLM, and the papers they cite). This finding is a consequence of dynamic complementarity and self-productivity captured by the technology developed in the next section.

Fourth, if early investment in disadvantaged children is not followed up by later investment, its effect at later ages is lessened. Investments appear to be complementary and require follow-up to be effective. Currie \& Thomas (1995) document a decline in the performance of Head Start $^{5}$ minority participants after they leave the program, return to disadvantaged environments, and receive the low levels of investment experienced by many disadvantaged children. ${ }^{6}$

Fifth, the effects of credit constraints on a child's outcomes when the child reaches adulthood depend on the age at which they bind for the child's family. Recent research summarized in Carneiro \& Heckman $(2002,2003)$ and in CHLM demonstrates the quantitative insignificance of family credit constraints in the child's college-going years in explaining a child's enrollment in college. Controlling for cognitive ability, under meritocratic policies currently in place in American society, family income during the child's college-going years plays only a minor role in determining child college participation, although much public policy is predicated on precisely the opposite point of view. Holding ability fixed, minorities are more likely to attend college than others despite their lower family incomes (see Cameron \& Heckman, 2001, and the references they cite). Augmenting family income or reducing college tuition at the stage of the life cycle when a child goes to college does not go far in compensating for low levels of previous investment.

Carneiro and Heckman present evidence for the United States that only a small fraction (at most $8 \%$ ) of the families of adolescents are credit constrained in making college participation decisions. This evidence is supported in research by Cameron \& Taber (2004) and Stinebrickner \& Stinebrickner (2008). Permanent family income plays an important role in explaining educational choices, insofar as it is a proxy for the high level of investment in abilities and skills that wealthier families provide, but it is not synonymous with family income in the adolescent years, nor with

\footnotetext{
${ }^{5}$ Head Start is a national program targeted to low-income pre-school aged children (ages 3-5) that promotes school readiness by enhancing their social and cognitive development through the provision of educational, health, nutritional, social and other services to enrolled children and families. There is a new program, Early Head Start, that begins at age 1 .

${ }^{6}$ Currie \& Thomas (2000) present additional analyses of the Head Start program.
} 
tuition and fees.

There is some evidence, however, that credit constraints operating in the early years have effects on adult ability and schooling outcomes (Dahl \& Lochner, 2005; Duncan \& Brooks-Gunn, 1997; Duncan \& Kalil, 2006; Morris, Duncan, \& Clark-Kauffman, 2005). Carneiro \& Heckman (2003) show that controlling for family permanent income reduces the estimated effect of early income on child outcomes. Permanent income has a strong effect on child outcomes. The strongest evidence for an effect of the timing of parental income for disadvantaged children is in their early years. The best documented market failure in the life cycle of skill formation in contemporary American society is the inability of children to buy their parents or the lifetime resources that parents provide and not the inability of families to secure loans for a child's education when the child is an adolescent.

Sixth, socioemotional (noncognitive) skills foster cognitive skills and are an important product of successful families and successful interventions in disadvantaged families. Emotionally nurturing environments produce more capable learners. The Perry Preschool Program, ${ }^{7}$ which was evaluated by random assignment, did not boost participant adult IQ but enhanced performance of participants on a number of dimensions, including scores on achievement tests, employment, and reduced participation in a variety of social pathologies. See Schweinhart, Montie, Xiang, Barnett, Belfield, \& Nores (2005).

\section{A Model of Skill Formation}

We now develop a model of skill formation that can explain the six facts just presented as well as additional findings from the literature on child development. We use the terms skill and ability interchangeably. Both are produced by environments, investment, and genes.

Agents possess a vector of abilities at each age. These abilities (or skills) are multiple in nature and range from pure cognitive abilities (e.g., IQ) to noncognitive abilities (patience, selfcontrol, temperament, risk aversion, time preference). These abilities are used with different weights in different tasks in the labor market and in social life more generally. ${ }^{8}$ Achievement test scores, sometimes confused with IQ scores (e.g., Herrnstein \& Murray, 1994), are not pure measures of ability and are affected by cognitive, noncognitive and environmental inputs. (See, e.g., Hansen, Heckman, \& Mullen, 2004, and Heckman, Stixrud, \& Urzua, 2006.)

The human skill-formation process is governed by a multistage technology. Each stage corresponds to a period in the life cycle of a child. Although the child development literature recognizes stages of development (see, e.g., Erikson, 1950), the economics of child development does not. Inputs or investments at each stage produce outputs at the next stage. Like Ben-Porath (1967), we

\footnotetext{
${ }^{7}$ The Perry Preschool Program was an intensive family-enhancement preschool program administered to randomly selected disadvantaged black children enrolled in the program over five different waves between 1962 and 1967 . Children were enrolled $2 \frac{1}{2}$ hours per day, 5 days a week, during the school year and there were weekly $1 \frac{1}{2}$-hour home visits. They were treated for 2 years, ages 3 and 4 . A control group provides researchers with an appropriate benchmark to evaluate the effects of the preschool program.

${ }^{8}$ CHLM briefly discuss the evidence on this point and suggest a model of comparative advantage in occupational choice to supplement their model of skill formation.
} 
use a production function to determine the relationship between inputs and the output of skill. Unlike Ben-Porath, in our model qualitatively different inputs can be used at different stages and the technologies can be different at different stages of child development.

Ben-Porath focuses on adult investments where time and its opportunity cost play important roles. For child investments, parents make decisions and child opportunity costs are less relevant. The outputs at each stage in our technology are the levels of each skill achieved at that stage. Some stages of the technology may be more productive in producing some skills than other stages, and some inputs may be more productive at some stages than at other stages. The stages that are more effective in producing certain skills are called "sensitive periods" for the acquisition of those skills. If one stage alone is effective in producing a skill (or ability), it is called a "critical period" for that skill.

An important feature of our technology is that the skills produced at one stage augment the skills attained at later stages. This effect is termed self-productivity. It embodies the idea that skills acquired in one period persist into future periods. It also embodies the idea that skills are self-reinforcing and cross-fertilizing. For example, emotional security fosters more vigorous learning of cognitive skills. This has been found in animal species (Suomi, 1999; Meaney, 2001; Cameron, 2004) and in humans (Duncan, Dowsett, Claessens, Magnuson, Huston, Klebanov et al., 2007; Raver, Garner, \& Smith-Donald, 2007, interpreting the ability of a child to pay attention as a socioemotional skill). A higher stock of cognitive skill in one period raises the stock of next period cognitive skills. A second key feature of skill formation is dynamic complementarity. Skills produced at one stage raise the productivity of investment at subsequent stages. In a multistage technology, complementarity implies that levels of skill investments at different ages bolster each other. They are synergistic. Complementarity also implies that early investment should be followed up by later investment in order for the early investment to be productive. Together, dynamic complementarity and self-productivity produce multiplier effects which are the mechanisms through which skills beget skills and abilities beget abilities.

Dynamic complementarity, self-productivity of human capital, and multiplier effects imply an equity-efficiency trade-off for late child investments but not for early investments. These concepts, embedded in alternative market settings, explain the six facts from the recent literature summarized in the previous section. These features of the technology of skill formation have consequences for the design and evaluation of public policies toward families. In particular, they show why the returns to late childhood investment and remediation for young adolescents from disadvantaged backgrounds are so low, while the returns to early investment in children from disadvantaged environments are so high.

We now formalize these concepts in an overlapping generations model. An individual lives for $2 T$ years. The first $T$ years the individual is a child of an adult parent. From age $T+1$ to $2 T$ the individual lives as an adult and is the parent of a child. The individual dies at the end of the period in which he is $2 T$ years old, just before his child's child is born. At every calendar year 
there are an equal and large number of individuals of every age $t \in\{1,2, \ldots, 2 T\} .{ }^{9}$ To simplify the notation, we do not explicitly subscript generations.

A household consists of an adult parent and his child. Parents invest in their children because of altruism. They have common preferences and supply labor inelastically. Let $I_{t}$ denote parental investments in child skill when the child is $t$ years old, where $t=1,2, \ldots, T$. The output of the investment process is a skill vector. The parent is assumed to fully control the investments in the skills of the child, whereas in reality, as a child matures, he gains much more control over the investment process. ${ }^{10}$ We ignore investments in the child's adult years to focus on new ideas in this paper. We also keep government inputs (e.g., schooling) implicit. They can be modeled as a component of $I_{t}$.

We now describe how skills evolve over time. Assume that each agent is born with initial conditions $\theta_{1}$. Let $h$ denote parental characteristics (e.g., IQ, education, etc.). At each stage $t$, let $\theta_{t}$ denote the vector of skill stocks. The technology of production of skill when the child is $t$ years old is

$$
\theta_{t+1}=f_{t}\left(h, \theta_{t}, I_{t}\right)
$$

for $t=1,2, \ldots, T$. We assume that $f_{t}$ is strictly increasing and strictly concave in $I_{t}$, and twice continuously differentiable in all of its arguments. ${ }^{11}$

Technology (1) is written in recursive form. Substituting in (1) for $\theta_{t}, \theta_{t-1}, \ldots$, repeatedly, one can rewrite the stock of skills at stage $t+1, \theta_{t+1}$, as a function of all past investments:

$$
\theta_{t+1}=m_{t}\left(h, \theta_{1}, I_{1}, \ldots, I_{t}\right), t=1, \ldots, T
$$

Dynamic complementarity arises when $\partial^{2} f_{t}\left(h, \theta_{t}, I_{t}\right) / \partial \theta_{t} \partial I_{t}^{\prime}>0$, (i.e., when stocks of skills acquired by period $t-1\left(\theta_{t}\right)$ make investment in period $t\left(I_{t}\right)$ more productive). Such complementarity explains why returns to educational investments are higher at later stages of the child's life cycle for more able children (those with higher $\theta_{t}$ ). Students with greater early skills (cognitive and noncognitive) are more efficient in later learning of both cognitive and noncognitive skills. The evidence from the early intervention literature suggests that the enriched early preschool environments provided by the Abecedarian, ${ }^{12}$ the Perry Preschool Program, and the Chicago Child-Parent Center $(\mathrm{CPC})^{13}$ interventions promote greater efficiency in learning in school and reduce problem

\footnotetext{
${ }^{9}$ We develop our formal OLG model in Cunha \& Heckman (2007).

${ }^{10} \mathrm{~A}$ sketch of such a model is discussed in Carneiro, Cunha, \& Heckman (2003).

${ }^{11}$ These conditions are sufficient. There is no need for a differentiability requirement for $h$, and the differentiability requirement with respect to $\theta_{t}$ can be weakened.

${ }^{12}$ The Abecedarian Project recruited children born between 1972 and 1977 whose families scored high on a "High Risk" index. It enrolls and enriches the family environments of disadvantaged children beginning a few months after birth and continuing until age 5. At age 5-just as they were about to enter kindergarten-all of the children were reassigned to either a school age intervention through age 8 or to a control group. The Abecedarian program was more intensive than the Perry program. Its preschool program was a year-round, full-day intervention.

${ }^{13}$ The CPC was started in 1967, in selected public schools serving impoverished neighborhoods of Chicago. Using federal funds, the center provided half-day preschool program for disadvantaged 3- and 4-year-olds during the 9 months that they were in school. In 1978, state funding became available, and the program was extended through third grade and included full-day kindergarten.
} 
behaviors (see Blau \& Currie (2006) and CHLM).

Self-productivity arises when $\partial f_{t}\left(h, \theta_{t}, I_{t}\right) / \partial \theta_{t}>0$ (i.e., when higher stocks of skills in one period create higher stocks of skills in the next period). For the case of skill vectors, this includes own- and cross-effects. The joint effects of self-productivity and dynamic complementarity help to explain the high productivity of investment in disadvantaged young children, and the lower return to investment in disadvantaged adolescent children for whom the stock of skills is low and hence the complementarity effect is lower. These are facts 2 and 3 presented in the "Observations About Human Diversity and Human Development and Some Facts Our Model Explains" Section.

This technology is sufficiently rich to describe learning in rodents and macaque monkeys. More emotionally secure young animals explore their environments more actively and learn more quickly. This technology also explains the evidence that the ability of the child to pay attention affects subsequent academic achievement. Cross-complementarity serves to explain fact 6 . This technology also captures the critical and sensitive periods in humans and animals documented by Knudsen, Heckman, Cameron, \& Shonkoff (2006). We now define these concepts precisely.

Period $t^{*}$ is a critical period for $\theta_{t+1}$ if

$$
\frac{\partial \theta_{t+1}}{\partial I_{s}}=\frac{\partial m_{t}\left(h, \theta_{1}, I_{1}, \ldots, I_{t}\right)}{\partial I_{s}} \equiv 0 \text { for all } h, \theta_{1}, I_{1}, \ldots, I_{t}, s \neq t^{*}
$$

but

$$
\frac{\partial \theta_{t+1}}{\partial I_{t^{*}}}=\frac{\partial m_{t}\left(h, \theta_{1}, I_{1}, \ldots, I_{t}\right)}{\partial I_{t^{*}}}>0 \text { for some } h, \theta_{1}, I_{1}, \ldots, I_{t} .
$$

This condition says that investments in $\theta_{t+1}$ are productive in period $t^{*}$ but not in any other period $s=t^{*}$. Period $t^{*}$ is a sensitive period for $\theta_{t+1}$ if

$$
\left.\frac{\partial \theta_{t+1}}{\partial I_{s}}\right|_{h=\bar{h}, \theta_{1}=\theta, I_{1}=i_{1}, \ldots, I_{t}=i_{t}}<\left.\frac{\partial \theta_{t+1}}{\partial I_{t^{*}}}\right|_{h=\bar{h}, \theta_{1}=\theta, I_{1}=i_{1}, \ldots, I_{t}=i_{t}} .
$$

In words, period $t^{*}$ is a sensitive period relative to period $s$ if, at the same level of inputs, investment is more productive in stage $t^{*}$ than in another stage $s \neq t^{*}{ }^{14}$

Suppose for simplicity that $T=2$. In reality, there are many stages in childhood, including in utero experiences. ${ }^{15}$ Assume that $\theta_{1}, I_{1}$, and $I_{2}$ are scalars. ${ }^{16}$ The adult stock of skills, $h^{\prime}\left(=\theta_{3}\right)$, is a function of parental characteristics, initial conditions, and investments during childhood $I_{1}$ and $I_{2}$ :

$$
h^{\prime}=m_{2}\left(h, \theta_{1}, I_{1}, I_{2}\right)
$$

The literature in economics assumes only one period of childhood. It does not distinguish between early investment and late investment. This produces the conventional specification which

\footnotetext{
${ }^{14}$ See CHLM for a definition of critical and sensitive periods in terms of technology (1).

${ }^{15}$ Our technology applies to in utero and post-natal investments as well. See Shonkoff \& Phillips (2000) for evidence on the importance of such investments.

${ }^{16}$ CHLM analyze the vector case.
} 
is a special case of technology (3), where

$$
h^{\prime}=m_{2}\left(h, \theta_{1}, \gamma I_{1}+(1-\gamma) I_{2}\right)
$$

and $\gamma=1 / 2$. In this case, adult stocks of skills do not depend on how investments are distributed over different periods of childhood. For example, take two children, $A$ and $B$, who have identical parents and the same initial condition $\theta_{1}$, but have different investment profiles: Child $A$ receives no investment in period 1 and receives $I$ units of investment in period $2, I_{1}^{A}=0, I_{2}^{A}=I$, while child $B$ receives $I$ units of investment in period 1 and zero units of investment in period $2, I_{1}^{B}=I$, $I_{2}^{B}=0$. According to (4), when $\gamma=1 / 2$, children $A$ and $B$ will have the same stocks of skills as adults. The timing of investment is irrelevant. Neither period 1 nor period 2 is critical.

The polar opposite of perfect substitution is perfect complementarity:

$$
h^{\prime}=m_{2}\left(h, \theta_{1}, \min \left\{I_{1}, I_{2}\right\}\right) .
$$

Technology (5) has the feature that adult stocks of skills critically depend on how investments are distributed over time. For example, if investment in period 1 is zero, $I_{1}=0$, then it does not pay to invest in period 2. If late investment is zero, $I_{2}=0$, it does not pay to invest early. For the technology of skill formation defined by (5), the best strategy is to distribute investments evenly, so that $I_{1}=I_{2}$. Complementarity has a dual face. It is essential to invest early to get satisfactory adult outcomes. But it is also essential to invest late to harvest the fruits of the early investment. ${ }^{17}$ Such dynamic complementarity helps to explain the evidence by Currie \& Thomas (1995) that for disadvantaged minority students, early investments through Head Start have weak effects in later years if not followed up by later investments. This is fact 4 on our list. Our explanation is in sharp contrast to the one offered by Becker (1991), who explains weak Head Start effects by crowding out of parental investment by public investment. That is a story of substitution against the child who receives investment in a one-period model of childhood. Ours is a story of dynamic complementarity. ${ }^{18}$

A more general technology that captures technologies (4) and (5) as special cases is a standard constant elasticity of substitution (CES):

$$
h^{\prime}=m_{2}\left(h, \theta_{1},\left[\gamma\left(I_{1}\right)^{\phi}+(1-\gamma)\left(I_{2}\right)^{\phi}\right]^{\frac{1}{\phi}}\right)
$$

for $\phi \leq 1$ and $0 \leq \gamma \leq 1$. The CES share parameter $\gamma$ is a skill multiplier. It reveals the productivity of early investment not only in directly boosting $h^{\prime}$ (through self-productivity) but also in raising the productivity of $I_{2}$ by increasing $\theta_{2}$ through first-period investments. Thus $I_{1}$ directly increases $\theta_{2}$ which in turn affects the productivity of $I_{2}$ in forming $h^{\prime} . \gamma$ captures the net effect of $I_{1}$ on $h^{\prime}$ through both self-productivity and direct complementarity.

\footnotetext{
${ }^{17}$ Both periods are critical. Note that in this case the production function is not strictly differentiable as required in our definition. Our definition can be extended to deal with this limit case.

${ }^{18}$ We offer another explanation of the apparently weak Head Start effects below.
} 
The elasticity of substitution $1 /(1-\phi)$ is a measure of how easy it is to substitute between $I_{1}$ and $I_{2}$. For a CES technology, $\phi$ represents the degree of complementarity (or substitutability) between early and late investment in producing skills. The parameter $\phi$ governs how easy it is to compensate for low levels of stage 1 skills in producing later skills.

When $\phi$ is small, low levels of early investment $I_{1}$ are not easily remediated by later investment $I_{2}$ in producing human capital. The other face of CES complementarity is that when $\phi$ is small, high early investment should be followed with high late investment if the early investment is to be harvested. In the extreme case when $\phi \rightarrow-\infty$, (6) converges to (5). This technology explains facts 2 and 3 - why returns to education are low in the adolescent years for disadvantaged (low $h$, low $I_{1}$, low $\theta_{2}$ ) adolescents but are high in the early years. Without the proper foundation for learning (high levels of $\theta_{2}$ ) in technology (1), adolescent interventions have low returns.

In a one-period model of childhood, inputs at any stage of childhood are perfect substitutes. Application of the one-period model supports the widely held but empirically unsupported intuition that diminishing returns make investment in less advantaged adolescents more productive. As noted in fact 2 of the "Observations About Human Diversity and Human Development and Some Facts Our Model Explains" Section, the evidence suggests that just the opposite is true. We next embed the technology in a market environment with parental choice of inputs.

\section{The Optimal Life Cycle Profile of Investments}

Using technology (6), we now show how the ratio of early to late investments varies as a function of $\phi$ and $\gamma$ as a consequence of parental choices in different market settings. Let $w$ and $r$ denote the wage and interest rates, respectively, in a stationary environment. At the beginning of adulthood, the parent draws the initial level of skill of the child, $\theta_{1}$, from the distribution $J\left(\theta_{1}\right)$. On reaching adulthood, the parent receives bequest $b$. The state variables for the parent are the parental skills, $h$, the parental financial resources, $b$, and the initial skill level of the child, $\theta_{1}$. Let $c_{1}$ and $c_{2}$ denote the consumption of the household in the first and second period of the life cycle of the child, respectively. The parent decides how to allocate the resources among consumption and investments at different periods as well as bequests $b^{\prime}$ which may be positive or negative. Assuming that human capital (parental and child) is scalar, the budget constraint is:

$$
c_{1}+I_{1}+\frac{c_{2}+I_{2}}{(1+r)}+\frac{b^{\prime}}{(1+r)^{2}}=w h+\frac{w h}{(1+r)}+b
$$

Let $\beta$ denote the utility discount factor and $\delta$ denote the parental altruism toward the child. Let $u(\cdot)$ denote the utility function. The recursive formulation of the problem of the parent is:

$$
V\left(h, b, \theta_{1}\right)=\max \left\{u\left(c_{1}\right)+\beta u\left(c_{2}\right)+\beta^{2} \delta E\left[V\left(h^{\prime}, b^{\prime}, \theta_{1}^{\prime}\right)\right]\right\} .
$$

The problem of the parent is to maximize (8) subject to (7) and technology (6).

When $\phi=1$, so early and late investment are perfect CES substitutes, the optimal investment strategy is straightforward. The price of early investment is $\$ 1$. The price of the late investment 
is $\$ 1 /(1+r)$. Thus the parent can purchase $(1+r)$ units of $I_{2}$ for every unit of $I_{1}$. The amount of human capital produced from one unit of $I_{1}$ is $\gamma$, while $\$(1+r)$ of $I_{2}$ produces $(1+r)(1-\gamma)$ units of human capital. Thus, two forces act in opposite directions. High productivity of initial investment (the skill multiplier $\gamma$ ) drives the parent toward making early investments. The interest rate drives the parent to invest late. It is optimal to invest early if $\gamma>(1-\gamma)(1+r)$.

As $\phi \rightarrow-\infty$, the CES production function converges to the Leontief case and the optimal investment strategy is to set $I_{1}=I_{2}$. In this case, investment in the young is essential. At the same time, later investment is needed to harvest early investment. On efficiency grounds, early disadvantages should be perpetuated, and compensatory investments at later ages are economically inefficient.

For $-\infty<\phi<1$, the first-order conditions are necessary and sufficient given concavity of the technology in terms of $I_{1}$ and $I_{2}$. For an interior solution, we can derive the optimal ratio of early to late investment:

$$
\frac{I_{1}}{I_{2}}=\left[\frac{\gamma}{(1-\gamma)(1+r)}\right]^{\frac{1}{1-\phi}}
$$

Figure 2 plots the ratio of early to late investment as a function of the skill multiplier $\gamma$ under different values of the complementarity parameter $\phi$, assuming $r=0$. When $\phi \rightarrow-\infty$, the ratio is not sensitive to variations in $\gamma$. When $\phi=0$, the function (6) is

$$
h^{\prime}=m_{2}\left(h, \theta_{1}, I_{1}, I_{2}\right)=m_{2}\left(h, \theta_{1}, I_{1}^{\gamma} I_{2}^{1-\gamma}\right) .
$$

In this case, from equation (9), the optimal $I_{1} / I_{2}$ is close to zero for low values of $\gamma$, but explodes to infinity as $\gamma$ approaches one.

When CES complementarity is high, the skill multiplier $\gamma$ plays a limited role in shaping the ratio of early to late investment. High early investment should be followed by high late investment. As the degree of CES complementarity decreases, the role of the skill multiplier increases, and the higher the multiplier, the more investment should be concentrated in the early ages.

In a perfect credit market model, optimal investment levels are not affected by parental wages or endowments, or the parameters that characterize the utility function $u(\cdot) .{ }^{19}$ Note, however, that even in this "perfect" credit market setting, parental investments depend on parental skills, $h$, because these characteristics affect the returns to investment. From the point of view of the child, this is a market failure due to the accident of birth. Children would like to choose the optimal amount of parental characteristics $h$ to complement their initial endowment, $\theta_{1} \cdot{ }^{20}$

Consider the second credit constraint mentioned in the introduction: parental bequests must be non-negative, i.e., parents cannot leave debts to their children. The problem of the parent is to

\footnotetext{
${ }^{19}$ We refer to parental resources specific to a given generation.

${ }^{20}$ This thought experiment is whimsical. If parents create the child, through genes and environment, the child is not an independent actor. Under a homunculus theory, the child would have an identity independent of the parent.
} 
Figure 2. Ratio of early to late investment in human capital as a function of the ratio of first period to second period investment productivity for different values of the complementarity parameter.

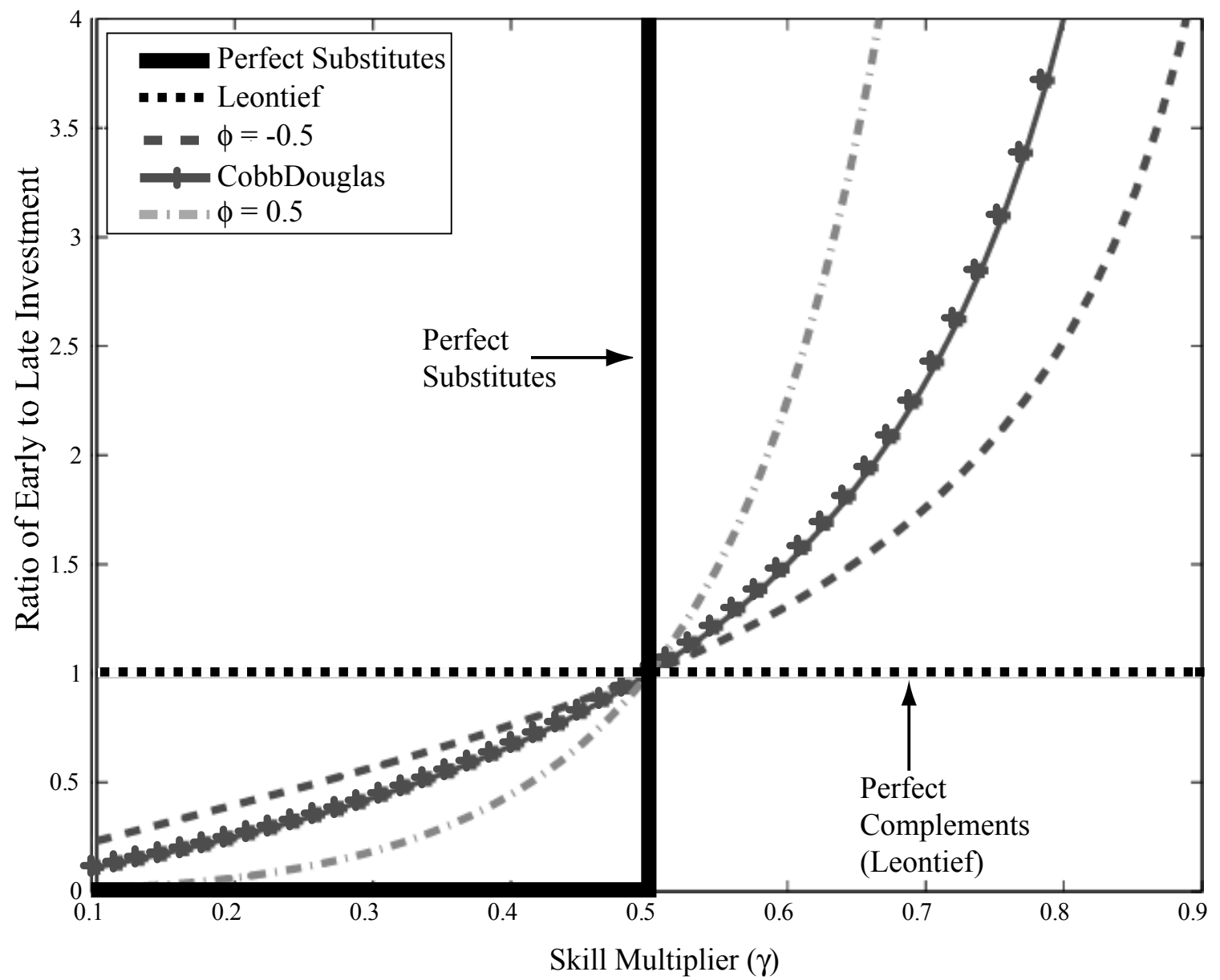

Note: Assumes $r=0$.

Source: Cunha and Heckman (2007).

maximize (8) subject to (7), technology (6), and the liquidity constraint:

$$
b^{\prime} \geq 0
$$

If constraint (10) binds, then early investment under lifetime liquidity constraints, $\hat{I}_{1}$, is lower than the early investment under the perfect credit market model, denoted $I_{1}^{*}$. The same is true for late investment: $\hat{I}_{2}<I_{2}^{*}$. Under this type of market imperfection, underinvestment in skills starts at early ages and continues throughout the life cycle of the child. This explains fact 1 - that skill gaps open up early and are perpetuated. ${ }^{21}$

In this second case, both early and late investment depend on parental initial wealth $b$ for the families for whom the constraint (10) binds. Children who come from constrained families

\footnotetext{
${ }^{21}$ Of course other reasons why skill gaps open up early and are perpetuated is variation in $h$ and $\theta_{1}$, the parental environmental and initial endowment variables, respectively.
} 
with lower $b$ will have lower early and late investment. Interventions that occur at early stages would exhibit high returns, especially if they are followed up with resources to supplement late investment. Once the early stage investment is realized, however, late remediation for disadvantaged children would produce lower returns if early and late investment are not perfect substitutes and late investment is more productive the higher the level of early investment. This helps to explain fact 5 in the "Observations About Human Diversity and Human Development and Some Facts Our Model Explains" Section.

The effects of government policies on promoting the accumulation of human capital depend on the complementarity between early and late investment as well as on whether the policies were anticipated by parents or not. For example, the short-run effects of an unanticipated policy that subsidizes late investment will have weaker effects the greater the complementarity between early and late investment. If the technology is Leontief, there is no short-run impact of the policy on adolescent investment. At the time the policy is announced, poor parents have already made their early investment decisions and, in the Leontief case, it is not possible to compensate by increasing late investment as a response to the subsidy.

There is, however, a long-run effect of the policy. If the policy is a permanent change announced before the child is born, new parents will adjust both early and late investment in response to the subsidy to late investment. Note that the same is true for an exogenous increase in the return to education. If there is strong complementarity between early and late investment, in the short run we would expect weak reactions to the increase in returns to education as gauged by adolescent investment decisions for the children from very poor family backgrounds, but stronger reactions in the long run. This analysis provides an explanation for why the college enrollment response to unanticipated increases in the returns to college were initially so strong for adolescents from advantaged families and initially so weak for adolescents from less advantaged families. Adolescents from less advantaged families are more likely to lack the foundational skills that make college going productive, compared to adolescents from more advantaged families.

There is no trade-off between equity and efficiency in early childhood investment. Government policies to promote early accumulation of human capital should be targeted to the children of poor families. However, the optimal second-period intervention for a child from a disadvantaged environment depends critically on the nature of technology (6). If $I_{1}$ and $I_{2}$ are perfect CES complements, then a low level of $I_{1}$ cannot be compensated at any level of investment by a high $I_{2}$. On the other hand, suppose that $\phi=1$, so the technology $m_{2}$ can be written with inputs as perfect CES substitutes. In this case, a second-period intervention can, in principle, eliminate initial skill deficits (low values of $I_{1}$ ). At a sufficiently high level of second-period investment, it is technically possible to offset low first-period investment, but it may not be cost effective to do so. If $\gamma$ is sufficiently low relative to $r$, it is more efficient to postpone investment.

The concepts of critical and sensitive periods are defined in terms of the technical possibilities of remediation. Many noneconomists frame the question of remediation for adverse environments in terms of what is technically possible - not what is economically efficient. Our analysis considers 
both technological possibilities and costs. From an economic point of view, critical and sensitive periods should be defined in terms of the costs and returns of remediation, and not solely in terms of technical possibilities.

Another source of market failure arises when parents are subject to lifetime liquidity constraints and constraints that prevent parents from borrowing against their own future labor income, which may affect their ability to finance investment in the child's early years. ${ }^{22}$ This is the third constraint considered in the introduction. To analyze this case, assume that parental productivity grows exogenously at rate $\alpha$. Let $s$ denote parental savings. We write the constraints facing the parent at each stage of the life cycle of the child as:

$$
\begin{gathered}
c_{1}+I_{1}+\frac{s}{(1+r)}=w h+b \\
c_{2}+I_{2}+\frac{b^{\prime}}{(1+r)}=w(1+\alpha) h+s
\end{gathered}
$$

where $s \geq 0$ and $b^{\prime} \geq 0$. The restriction $s \geq 0$ says that the parent cannot borrow income from their old age to finance consumption and investment when the child is in the first stage of the life cycle. Some parents may be willing to do this, especially when $\alpha$ is high. In the case when $s \geq 0$ and $b^{\prime} \geq 0$ bind, and investments in different periods are not perfect substitutes, the timing of income matters. To see this, note that if $u(c)=\left(c^{\sigma}-1\right) / \sigma$, the ratio of early to late investment is

$$
\frac{I_{1}}{I_{2}}=\left[\frac{\gamma}{(1-\gamma)(1+r)}\right]^{\frac{1}{1-\phi}}\left[\frac{\left(w h+b-I_{1}\right)}{\beta\left((1+\alpha) w h-I_{2}\right)}\right]^{\frac{1-\sigma}{1-\phi}}
$$

If early income is low with respect to late income, the ratio $I_{1} / I_{2}$ will be lower than the optimal ratio. The deviation from the optimal ratio will be larger the lower the elasticity of intertemporal substitution of consumption (captured by the parameter $\sigma$ ). Early income would not matter if $\sigma=1$, which would be the case when consumption in stage 1 is a perfect substitute for consumption in stage 2. Substitutability through parental preferences can undo lack of substitutability in the technology of skill formation.

Our analysis of credit constrained families joined with a low value of $\phi$ interprets the evidence presented by Duncan \& Brooks-Gunn (1997), Morris, Duncan, \& Clark-Kauffman (2005), Duncan \& Kalil (2006), and Dahl \& Lochner (2005) that the level of family income in the early stages of childhood has some effect on the level of ability and achievement of the children. This is fact 5 of the "Observations About Human Diversity and Human Development and Some Facts Our Model Explains" Section. Our analysis also interprets the evidence of Carneiro \& Heckman (2002) and Cameron \& Taber (2004) that, conditioning on child ability, family income in the adolescent years has only a minor effect on adolescent schooling choices.

\footnotetext{
${ }^{22}$ This type of constraint is also analyzed by Caucutt \& Lochner (2004).
} 


\section{Cognitive and Noncognitive Skill Formation}

A large body of research documents the socio-emotional basis of reason (see Damasio, 1994, and LeDoux, 1996). Our analysis goes beyond this literature to formalize a body of evidence that emotional skills promote learning. Mechanisms relating cortisol to stress and the effects of cortisol on the brain development of animals have been documented by Suomi (1999) and Meaney (2001). Duncan, Dowsett, Claessens, Magnuson, Huston, Klebanov et al. (2007) and Raver, Garner, \& Smith-Donald (2007) show that a child's ability to pay attention facilitates later learning.

The framework developed in the "A Model of Skill Formation" Section readily accommodates skill vectors. The evidence summarized in the "Observations About Human Diversity and Human Development and Some Facts Our Model Explains" Section shows the importance of both cognitive and noncognitive skills in determining adult outcomes. Child development is not just about cognitive skill formation, although a lot of public policy analysis focuses solely on cognitive test scores. Let $\theta_{t}$ denote the vector of cognitive and noncognitive skills: $\theta_{t}=\left(\theta_{t}^{C}, \theta_{t}^{N}\right)$. Let $I_{t}$ denote the vector of investment in cognitive and noncognitive skills: $I_{t}=\left(I_{t}^{C}, I_{t}^{N}\right)$. We use $h=\left(h^{C}, h^{N}\right)$ to denote parental cognitive and noncognitive skills. At each stage $t$, we can define a recursive technology for cognitive skills $(k=C)$, and noncognitive skills, $(k=N)$ :

$$
\theta_{t+1}^{k}=f_{t}^{k}\left(\theta_{t}, I_{t}^{k}, h\right), k \in\{C, N\}
$$

Note that technology (11) allows for cross-productivity effects: cognitive skills may affect the accumulation of noncognitive skills and vice versa. They also allow for critical and sensitive periods to differ by skill, as is required to account for fact 2 .

If cognitive and/or noncognitive skills determine costs of effort, time preference, or risk aversion parameters, parental investments affect child and adult behavior. Our analysis of preference formation contrasts with the analyses of Akabayashi (1996) and Weinberg (2001). Those authors build principal-agent models where the parent (the principal) and the child (the agent) agree on contracts in which parents' financial transfers are conditional on observable measures of effort (e.g., test scores in school). These contracts are designed so that the children are driven toward the level of effort desired by the parents. In our model, parents directly shape child preferences.

Accounting for preference formation enables us to interpret the success of many early childhood programs targeted to disadvantaged children that do not permanently raise IQ, but which permanently boost social performance. ${ }^{23}$ This is fact 6 of the "Observations About Human Diversity and Human Development and Some Facts Our Model Explains" Section. The controversy over Head Start fade-out may have been a consequence of relying only on cognitive measures to gauge performance. The Perry Preschool Program had an IQ fade-out but a lasting effect on a variety of participants through age 40. They work harder, are less likely to commit crime, and participate in many fewer social pathologies than do control group members. ${ }^{24}$

\footnotetext{
${ }^{23}$ The Abecedarian early intervention program permanently boosted adult IQ. See CHLM.

${ }^{24}$ See Cunha \& Heckman (2009). The exact mechanism by which noncognitive skills are boosted is not yet established. It could be that noncognitive skills are created directly in the early years and persist. It could also be that
} 


\section{Estimates of the Technology}

\section{Parametric Specification}

We specify the following parametric representation of equation (11). At each age $t$ and developmental stage $l$, the technology for the production of skill $j$ writes:

$$
\begin{aligned}
\theta_{t+1}^{j} & =\left[\gamma_{C, l}^{j}\left(\theta_{t}^{C}\right)^{\phi_{l}^{j}}+\gamma_{N, l}^{j}\left(\theta_{t}^{N}\right)^{\phi_{l}^{j}}+\gamma_{I, l}^{j}\left(I_{t}^{j}\right)^{\phi_{l}^{j}}+\gamma_{P, l}^{j}\left(\theta_{t}^{P}\right)^{\phi_{l}^{j}}\right]^{\frac{1}{\phi_{l}^{j}}} e^{\eta_{t+1}^{j}} \\
1 & \geq \phi_{l}^{j}, \gamma_{k, l}^{j} \geq 0, \quad \sum_{k} \gamma_{k, l}^{j}=1 \text { for all } j \in\{C, N\}, l \in\{1, \ldots, L\}, \text { and } t \in\{1, \ldots, T\} .
\end{aligned}
$$

It is useful to consider a simpler version of (12) which one obtains if $\phi_{l}^{j}=0$ for all $j$ and $l$ and if the components of $\theta_{t}, I_{t}$ and $h$ are expressed in logs:

$$
\theta_{t+1}^{j}=\gamma_{C, l}^{j} \theta_{t}^{C}+\gamma_{N, l}^{j} \theta_{t}^{N}+\gamma_{I, l}^{j} I_{t}^{j}+\gamma_{P, l}^{j} \theta_{t}^{P}+\eta_{t+1}^{j}
$$

Technology (13) is estimated by Cunha \& Heckman (2008). The main problem that arises in estimating the technology is that vector $\left(\theta_{t}, I_{t}\right)$ is not directly observed. Cunha \& Heckman (2008) treat $\left(\theta_{t}, I_{t}\right)$ as a vector of unobserved factors and use a variety of measurements of the latent constructs to proxy these factors. There is a substantial body of econometric work on linear factor models (see, e.g., Aigner, Hsiao, Kapteyn, \& Wansbeek, 1984). These models account for measurement errors in the proxies which Cunha \& Heckman (2008) find to be quantitatively large. If they are not accounted for, estimates of technology parameters are substantially biased.

In addition to the problem of measurement error, there is the problem of setting the scale of the factors and the further problem that elements of $\left(\theta_{t}, I_{t}\right)$ are likely correlated with the shock $\eta_{t}$. Cunha \& Heckman (2008) address these problems by using rich sources of panel data which provide multiple measurements on $\left(\theta_{t}, I_{t}\right)$. They use a dynamic state-space version of a MIMIC model. ${ }^{25}$ In the linear setting, it is assumed that multiple measurements on inputs and outputs can be represented by a linear factor setup:

$$
Y_{j, t}^{k}=\mu_{j, t}^{k}+\alpha_{j, t}^{k} \theta_{t}^{k}+\varepsilon_{j, t}^{k}, \text { for } j \in\left\{1, \ldots, M_{t}^{k}\right\}, k \in\{C, N, I\}
$$

where $M_{t}^{k}$ is the number of measurements on latent factor $k$ and $\theta_{t}^{I}$ is latent investment at age $t$.

This approach generalizes to a nonlinear semiparametric framework. Equation (12) can be interpreted as a general nonlinear factor model defined in terms of $\theta_{t}$ and $I_{t}{ }^{26}$ Cunha, Heckman, \& Schennach (2010) generalize this framework to a nonlinear setup to identify technology (1). They

the higher early cognitive skills that fade out foster noncognitive skills that persist. Both channels of influence could be in operation.

${ }^{25}$ See Jöreskog \& Goldberger (1975) MIMIC stands for Multiple Indicators and Multiple Causes. Harvey (1989) and Durbin, Harvey, Koopman, \& Shephard (2004) are standard references for dynamic state space models, which generalize MIMIC models to a dynamic setting.

${ }^{26}$ Nonlinear factor models are generated by economic choice models where risk aversion, time preference, and leisure preferences are low-dimensional factors that explain a variety of consumer choices. 
present original results on identification of dynamic factor models in nonlinear frameworks.

\section{Model Identification}

As is standard in factor analysis, Cunha \& Heckman (2008) use covariance restrictions to identify technology (13). Low dimensional $\left(\theta_{t}, I_{t}\right)$ (associated with preferences, abilities, and investment) are proxied by numerous measurements for each component.

Treating each of a large number of measurements on inputs as separate inputs creates a problem for instrumental variables analyses of production functions. It is easy to run out of instruments for each input. Such an approach likely also creates collinearity problems among the inputs.

Cunha and Heckman avoid these problems by assuming that clusters of measurements proxy the same set of latent variables. Measurements of a common set of factors can be used as instruments for other measurements on the same common set of factors. Methods based on covariance restrictions and cross-equation restrictions provide identification and account for omitted inputs that are correlated with included inputs. These methods provide an econometrically justified way to aggregate inputs into low-dimensional indices.

\section{Estimates from the Linear Model}

Cunha \& Heckman (2008) estimate technology (13) using a sample of white males from the Children of the National Longitudinal Survey of Youth data (CNLSY). These data provide multiple measurements on investments and cognitive and noncognitive skills at different stages of the life cycle of the child. Table 1, extracted from their paper, reports estimates of technology (13). The scales of the factors in $\theta_{t}$ are anchored in log earnings. ${ }^{27}$ They account for endogeneity of parental investment. Doing so substantially affects their estimates.

Their estimates show strong self-productivity effects (lagged coefficients of own variables) and strong cross-productivity of effects of noncognitive skills on cognitive skills (personality factors promote learning; those open to experience learn from it). The estimated cross-productivity effects of cognitive skills on noncognitive skills are weak. Contrary to models in criminology and psychology that assign no role to investment in explaining the life cycle evolution of capabilities, Cunha \& Heckman (2008) find strong investment effects. Remediation and resilience are possible. Capabilities evolve and are affected by parental investment. Investment affects cognitive skills more at earlier ages than at later ages. Investment affects noncognitive skills more in middle childhood. This evidence is consistent with the literature in neuroscience on the slow maturation of the prefrontal cortex which governs personality development and expression, and the emergence of more nuanced manifestations of personality with age.

One way to interpret these estimates is to examine the impacts of investment at each age on high school graduation and adult earnings. ${ }^{28}$ These outcomes depend differently on cognition and personality. Schooling attainment is more cognitively weighted than earnings.

\footnotetext{
${ }^{27}$ See Cunha \& Heckman (2008) for a discussion of alternative anchors for $\theta_{t}$ and $I_{t}$.

${ }^{28}$ Results for high school graduation as an anchor are reported in Cunha \& Heckman (2008).
} 
Table 1: Correcting for Classical Measurement Error Anchor-Log Earnings of the Child Between Ages 23-28 White Males, CNLSY.

\begin{tabular}{lccccccc}
\hline \multirow{2}{*}{ Independent variable } & \multicolumn{3}{c}{ Noncognitive skill $\left(\theta_{t+1}^{N}\right)$} & \multicolumn{5}{c}{ Cognitive skill $\left(\theta_{t+1}^{C}\right)$} \\
& Stage 1 & Stage 2 & Stage 3 & Stage 1 & Stage 2 & Stage 3 \\
\hline Lagged noncognitive skill, $\left(\theta_{t}^{N}\right)$ & 0.9849 & 0.9383 & 0.7570 & 0.0216 & 0.0076 & 0.0005 \\
& $(0.014)$ & $(0.015)$ & $(0.010)$ & $(0.004)$ & $(0.003)$ & $(0.003)$ \\
Lagged cognitive skill, $\left(\theta_{t}^{C}\right)$ & 0.1442 & -0.1259 & 0.1171 & 0.9197 & 0.8845 & 0.9099 \\
& $(0.120)$ & $(0.115)$ & $(0.115)$ & $(0.023)$ & $(0.021)$ & $(0.019)$ \\
Parental investment, $\left(\theta_{t}^{I}\right)$ & 0.0075 & 0.0149 & 0.0064 & 0.0056 & 0.0018 & 0.0019 \\
\multirow{3}{*}{ Maternal education, $S$} & $(0.002)$ & $(0.003)$ & $(0.003)$ & $(0.002)$ & $(0.001)$ & $(0.001)$ \\
& 0.0005 & -0.0004 & 0.0019 & -0.0003 & 0.0007 & 0.0001 \\
Maternal cognitive skill, $A$ & $(0.001)$ & $(0.001)$ & $(0.001)$ & $(0.001)$ & $(0.001)$ & $(0.001)$ \\
& 0.0001 & -0.0011 & -0.0019 & 0.0025 & 0.0002 & 0.0010 \\
& $(0.000)$ & $(0.000)$ & $(0.000)$ & $(0.001)$ & $(0.000)$ & $(0.000)$
\end{tabular}

Note: Standard errors in parentheses. Cognitive skills are proxied by PIAT math and reading. Noncognitive skills are proxied by the components of the behavioral problem index. Investments are proxied by components of the home score. Stage 1 is age $6-7$ to $8-9$; Stage 2 is $8-9$ to $10-11$; Stage 3 is $10-11$ to $12-13$. Source: Cunha \& Heckman (2008, Table 11).

The estimated effects of a 10\% increase in investment are reported in Table 2 (right panel for earnings and left panel for high school graduation). Increasing investment in the first stage by $10 \%$ increases adult earnings by $0.25 \%$. The increase operates equally through cognitive and noncognitive skills. Ten percent investment increments in the second stage have a larger effect $(0.3 \%)$ but mainly operate through improving noncognitive skills. Investment in the third stage has weaker effects and operates primarily through its effect on noncognitive skills.

For high school graduation (see left panel, Table 2), the effects are more substantial and operate relatively more strongly through cognitive skills rather than through noncognitive skills. The sensitive stage for the production of earnings is stage 2. The sensitive stage for producing secondary school graduation is stage 1 . This reflects the differential dependence of the outcomes on the two capabilities and the greater productivity of investment in noncognitive skills in the second period compared to other periods. This evidence is consistent with other evidence that shows the greater malleability of noncognitive skills at later ages. ${ }^{29}$

\footnotetext{
${ }^{29}$ See Cunha, Heckman, Lochner, \& Masterov (2006), Cunha \& Heckman (2007), and Heckman (2008) for a discussion of this evidence.
} 
Table 2: Percentage Impact of an Exogenous Increase by 10\% in Investments of Different Periods for Two Different Anchors White Males, CNLSY/79

\begin{tabular}{|c|c|c|c|c|c|}
\hline \multicolumn{3}{|c|}{ Log earnings at age $23-28$} & \multicolumn{3}{|c|}{ Probability of graduating from high school } \\
\hline $\begin{array}{c}\text { Total } \\
\text { percentage } \\
\text { impact }\end{array}$ & $\begin{array}{l}\text { Percentage } \\
\text { impact } \\
\text { exclusively } \\
\text { through } \\
\text { cognitive skills }\end{array}$ & $\begin{array}{l}\text { Percentage impact } \\
\text { exclusively } \\
\text { through } \\
\text { noncognitive skills }\end{array}$ & $\begin{array}{c}\text { Total } \\
\text { percentage } \\
\text { impact }\end{array}$ & $\begin{array}{c}\text { Percentage } \\
\text { impact } \\
\text { exclusively } \\
\text { through } \\
\text { cognitive skills }\end{array}$ & $\begin{array}{l}\text { Percentage impact } \\
\text { exclusively } \\
\text { through } \\
\text { noncognitive skills }\end{array}$ \\
\hline \multicolumn{3}{|c|}{ Period 1} & \multicolumn{3}{|c|}{ Period 1} \\
\hline $\begin{array}{c}0.2487 \\
(0.0302)\end{array}$ & $\begin{array}{c}0.1247 \\
(0.0151)\end{array}$ & $\begin{array}{c}0.1240 \\
(0.0150)\end{array}$ & $\begin{array}{c}0.6441 \\
(0.0789)\end{array}$ & $\begin{array}{c}0.5480 \\
(0.0672)\end{array}$ & $\begin{array}{c}0.0961 \\
(0.0118)\end{array}$ \\
\hline \multicolumn{3}{|c|}{ Period 2} & \multicolumn{3}{|c|}{ Period 2} \\
\hline $\begin{array}{c}0.3065 \\
(0.0358)\end{array}$ & $\begin{array}{c}0.0445 \\
(0.0052)\end{array}$ & $\begin{array}{c}0.2620 \\
(0.0306)\end{array}$ & $\begin{array}{c}0.3980 \\
(0.0466)\end{array}$ & $\begin{array}{c}0.1951 \\
(0.0229)\end{array}$ & $\begin{array}{c}0.2029 \\
(0.0238)\end{array}$ \\
\hline \multicolumn{3}{|c|}{ Period 3} & \multicolumn{3}{|c|}{ Period 3} \\
\hline $\begin{array}{c}0.2090 \\
(0.0230)\end{array}$ & $\begin{array}{c}0.0540 \\
(0.0059)\end{array}$ & $\begin{array}{c}0.1550 \\
(0.0170)\end{array}$ & $\begin{array}{c}0.3565 \\
(0.0389)\end{array}$ & $\begin{array}{c}0.2366 \\
(0.0258)\end{array}$ & $\begin{array}{c}0.1198 \\
(0.0131)\end{array}$ \\
\hline
\end{tabular}

Note. From Cunha \& Heckman (2008, Table 17). Standard errors in parentheses.

\section{Measurement Error}

Accounting for measurement error substantially affects estimates of the technology of skill formation. This evidence sounds a note of caution for the burgeoning literature that regresses wages on psychological measurements. The share of error variance for proxies of cognition, personality, and investment ranges from $30 \%$ to $70 \%$. Not accounting for measurement error produces downwardbiased estimates of self-productivity effects and perverse estimates of investment effects. ${ }^{30}$

\section{Estimates from Nonlinear Technologies}

Cunha, Heckman, \& Schennach (2010) estimate nonlinear technologies to identify key substitution parameters. ${ }^{31}$ The ability to substitute critically affects the design of strategies for remediation and early intervention.

Cunha, Heckman, \& Schennach (2010) estimate a version of technology (12) for general $\phi_{l}^{j}, j \in\{C, N\}, l \in\{1, \ldots, L\}$ using the same sample as used by Cunha \& Heckman (2008). ${ }^{32}$ They estimate a two-stage model of childhood $(L=2)$. Stage 1 is birth through age 4 . Stage 2 corresponds to age 5 through 14 .

The major findings from their analysis are: (a) Self-productivity becomes stronger as children become older, for both cognitive and noncognitive capability formation. (b) Complementarity between cognitive skills and investment becomes stronger as children become older. The elasticity of substitution for cognitive inputs is smaller in second-stage production. ${ }^{33}$ It is more difficult to compensate for the effects of adverse environments on cognitive endowments at later ages than it is at earlier ages. This finding helps to explain the evidence on ineffective cognitive remediation

\footnotetext{
${ }^{30}$ See Cunha \& Heckman (2008), Table 14.

${ }^{31}$ They also account for measurement error and endogeneity of family inputs.

${ }^{32}$ They establish semiparametric identification of their model, including measurement equations.

${ }^{33} \mathrm{It}$ is 1.5 in the first stage and .56 in the second stage. The estimates are precisely determined.
} 
strategies for disadvantaged adolescents. (c) Complementarity between noncognitive skills and investments becomes weaker as children become older. It is easier at later stages of childhood to remediate early disadvantage using investments in noncognitive skills. ${ }^{34}$

Cunha, Heckman, \& Schennach (2010) report that $34 \%$ of the variation in educational attainment in their sample is explained by the measures of cognitive and noncognitive capabilities that they use. ${ }^{35}$ Sixteen percent is due to adolescent cognitive capabilities. $12 \%$ is due to adolescent noncognitive capabilities. ${ }^{36}$ Measured parental investments account for $15 \%$ of the variation in educational attainment. These estimates suggest that the measures of cognitive and noncognitive capabilities that they use are powerful, but not exclusive, determinants of educational attainment and that other factors, besides the measures of family investment that they use, are at work in explaining variation in educational attainment.

\section{Lessons for the Design of Policies}

To examine the implications of the estimates of Cunha, Heckman, \& Schennach (2010), consider two social planning problems that can be solved from knowledge of the technology of capability formation and without knowledge of parental preferences and parental access to lending markets. The first problem we consider determines the cost of investment required to produce high school attainment for children with different initial endowments of their own and parental capabilities. For the same distribution of endowments, the second problem determines optimal allocations of investments from a fixed budget to maximize aggregate schooling for a cohort of children. We also consider a version of the social planning problem that minimizes aggregate crime.

Suppose that there are $H$ children indexed by $h \in\{1, \ldots, H\}$. Let $\left(\theta_{1, h}^{C}, \theta_{1, h}^{N}\right)$ denote the initial cognitive and noncognitive skills of child $h$. She has parents with cognitive and noncognitive skills denoted by $\left(\theta_{C, h}^{P}, \theta_{N, h}^{P}\right)$. Let $\pi_{h}$ denote additional unobserved determinants of outcomes. Define $\theta_{1, h}=\left(\theta_{1, h}^{C}, \theta_{1, h}^{N}, \theta_{C, h}^{P}, \theta_{N, h}^{P}, \pi_{h}\right)$ and let $G\left(\theta_{1, h}\right)$ be its distribution. We draw $H$ people from the initial distribution $G\left(\theta_{1, h}\right)$ that is estimated by Cunha, Heckman, \& Schennach (2010). The price of investment is assumed to be the same in each period, and is set at unity.

The criterion adopted for the first problem assumes that the goal of society is to get the schooling of every child to a 12th grade level. The required investments measure the power of initial endowments in determining inequality and the compensation through investment required to eliminate their influence. Let $v\left(\theta_{1, h}\right)$ be the minimum cost of attaining 12 years of schooling for a child with endowment $\theta_{1, h}$. Assuming a zero discount rate, $v\left(\theta_{1, h}\right)$ is formally defined by

$$
v\left(\theta_{1, h}\right)=\min \left\{I_{1, h}+I_{2, h}\right\}
$$

\footnotetext{
${ }^{34}$ The elasticity of substitution is .54 in the first stage and .77 in the second stage. The estimates are precisely determined.

${ }^{35}$ These are the same measures as used in Cunha \& Heckman (2008) which we previously discussed.

${ }^{36}$ The skills are correlated so the marginal contributions of each skill do not add up to $34 \%$.
} 
subject to a schooling constraint $S\left(\theta_{3, h}^{C}, \theta_{3, h}^{N}, \pi_{h}\right)=12$ where $S$ maps end-of-childhood capabilities and other relevant factors $\left(\pi_{h}\right)$ into schooling attainment, and also subject to the technology of capability formation constraint

$$
\theta_{t+1, h}^{k}=f_{k, t}\left(\theta_{t, h}^{C}, \theta_{t, h}^{N}, \theta_{C, h}^{P}, \theta_{N, h}^{P}, I_{t, h}, \pi_{h}\right) \text { for } k \in\{C, N\} \text { and } t \in\{1,2\},
$$

and the initial endowments of the child and her parents. Cunha, Heckman, \& Schennach (2010) estimate all of the ingredients needed to perform this calculation. We summarize some of their findings here.

Figure 3 plots the percentage increase in investment over that required for a child with mean parental and personal endowments to attain high school graduation. In analyzing the investment required for child endowments, we set parental endowments at mean values. Lighter values correspond to larger numbers. Eighty percent more investment is required for children with the most disadvantaged personal endowments. The negative percentages shown in Figure 3 for children with high initial endowments is a measure of their advantage. ${ }^{37}$ The empirical analysis of Moon (2010) shows that investments received as a function of a child's endowments are typically in reverse order from what is required to attain the goal of universal high school graduation. Children born with advantageous endowments typically receive more parental investment than children from less advantaged environments.

A more standard social planner's problem maximizes aggregate human capital subject to a budget constraint $B$. We draw $H$ children from the initial distribution $G\left(\theta_{1, h}\right)$, and solve the problem of how to allocate finite resources $B$ to maximize the average education of the cohort. Formally, the social planner maximizes aggregate per capita schooling

$$
\max \bar{S}=\frac{1}{H} \sum_{h=1}^{H} S\left(\theta_{3, h}^{C}, \theta_{3, h}^{N}, \pi_{h}\right)
$$

subject to the aggregate budget constraint,

$$
\sum_{h=1}^{H}\left(I_{1, h}+I_{2, h}\right)=B,
$$

the technology constraint,

$$
\theta_{t+1, h}^{k}=f_{k, t}\left(\theta_{t, h}^{C}, \theta_{t, h}^{N}, \theta_{C, h}^{P}, \theta_{N, h}^{P}, \pi_{h}\right) \text { for } k \in\{C, N\} \text { and } t \in\{1,2\}
$$

and the initial conditions of the child. Solving this problem, we obtain optimal early and late investments, $I_{1, h}$ and $I_{2, h}$, respectively, for each child $h$. An analogous social planning problem is used to allocate investments to minimize crime.

\footnotetext{
${ }^{37}$ The corresponding figure for children with the most disadvantaged parental endowments is $95 \%$. See Cunha, Heckman, \& Schennach (2010).
} 
Figure 3. Percentage increase in total investments as a function of child initial conditions of cognitive and noncognitive skills.

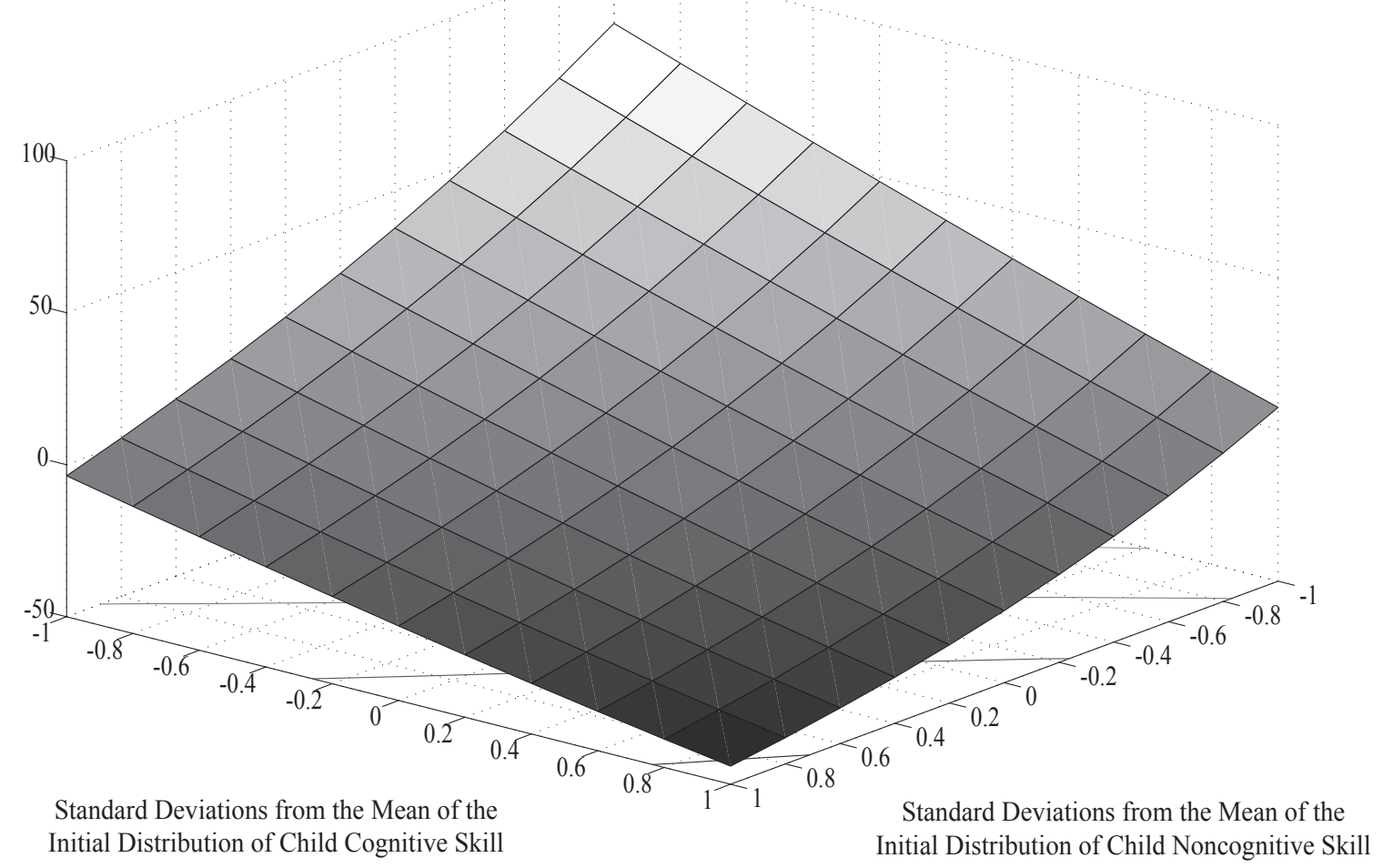

Figure 4 shows the profile of early (graph on left) and late (graph on right) investment as a function of endowments. For the most disadvantaged, the optimal policy is to invest a lot in the early years. The decline in investment by level of initial advantage is substantial for early investment. Second-period investment profiles are much flatter and slightly favor more advantaged children. This is a manifestation of the dynamic complementarity that produces an equity-efficiency trade-off for later stage investment but not for early investment. It is socially optimal to invest more in the second period of the lives of advantaged children than in disadvantaged children. A similar profile emerges for investments to reduce aggregate crime. ${ }^{38}$

The optimal ratio of early-to-late investment depends on the desired outcome, the endowments of children and budget $B$. Figure 5 plots the density of the ratio of early-to-late investment for education and crime derived by Cunha, Heckman, \& Schennach (2010). ${ }^{39}$ Whereas educational attainment depends strongly on cognitive skills, participation in criminal activities are affected strongly by noncognitive skills. Because compensation for adversity in noncognitive skills is less costly in the second period than in the first period, while the opposite is true for cognitive skills, it is optimal to weight first-period and second-period investments in the directions indicated in the figure. For most configurations of disadvantage, we have that the optimal policy to invest relatively

\footnotetext{
${ }^{38}$ See Cunha, Heckman, \& Schennach (2010). They report investment profiles similar to those displayed in Figure 4 when they plot optimal investment against parental endowments.

${ }^{39}$ The optimal policy is not identical for each $h$ and depends on $\theta_{1, h}$, which varies in the population. The densities reflect this variation.
} 
Figure 4. Optimal early (left) and late (right) investments by child initial conditions of cognitive and noncognitive skills maximizing aggregate education.
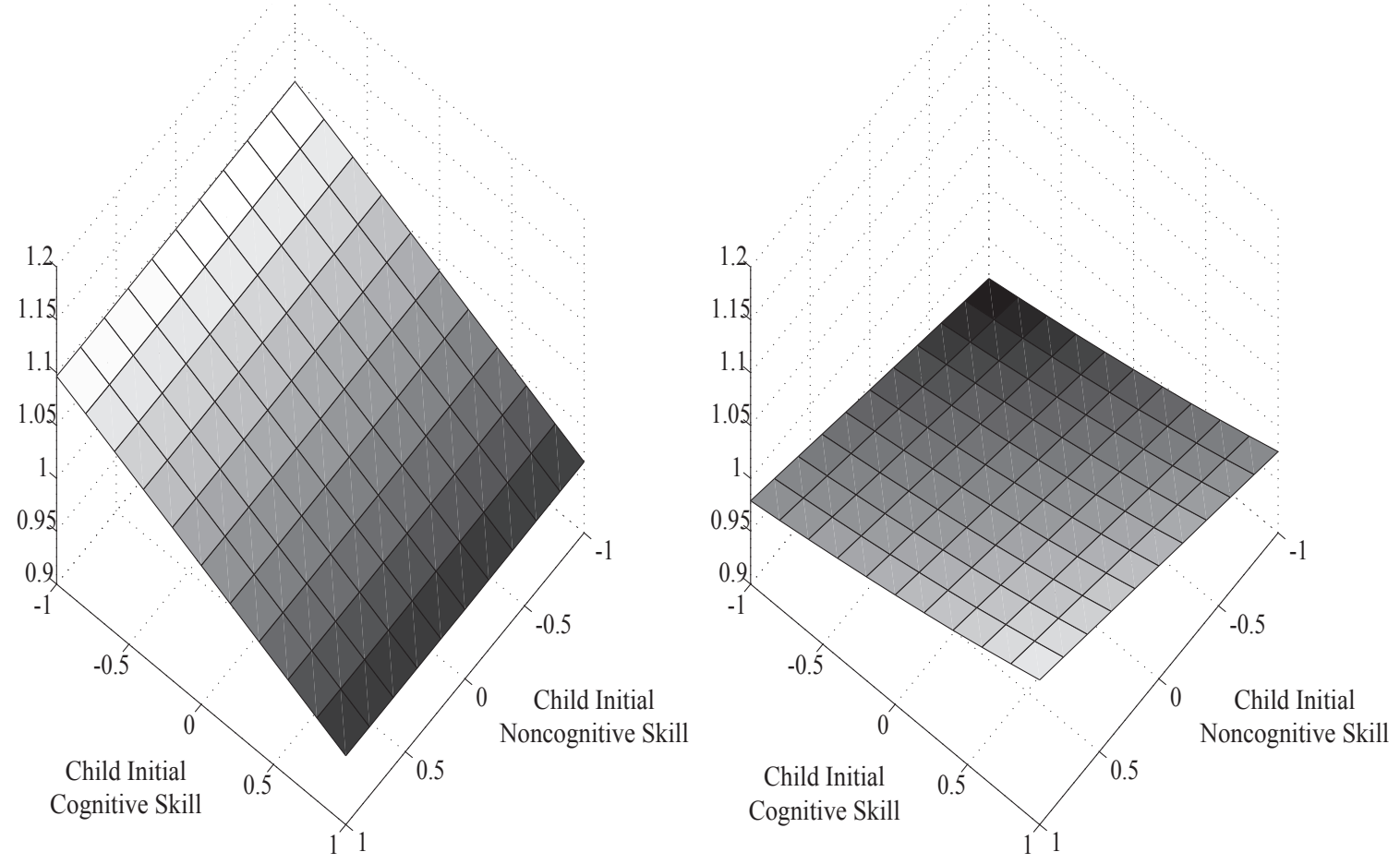

more in the early years, compared to the later years.

These simulations suggest that the timing and level of optimal interventions for disadvantaged children depend on the conditions of disadvantage and the nature of desired outcomes. ${ }^{40}$ Targeted strategies are likely to be effective, especially so if different targets weight cognitive and noncognitive traits differently.

\section{Summary and Conclusion}

This paper reviews the evidence from recent research that addresses the origins of inequality and the evolution of the capabilities that partly determine inequality. Both cognitive and noncognitive capabilities are important in producing a variety of outcomes. An emerging literature relates psychological measurements of personality and cognition to economic preference parameters and extends conventional preference specifications in economics.

Comparative advantage is an empirically important feature of economic and social life. The same bundle of personal traits has different productivity in different tasks. Recent empirical work on the technology of capability formation provides an operational empirical framework. Capabilities are not invariant traits and are causally affected by parental investment. Genes and environments interact to determine outcomes. The technology of capability formation rationalizes a large body of evidence in economics, psychology, and neuroscience. Capabilities are self-productive and cross-

\footnotetext{
${ }^{40}$ See Cunha, Heckman, \& Schennach (2010) for an extensive discussion of these and other simulations.
} 
Figure 5. Densities of ratio of early to late investments maximizing aggregate education versus minimizing aggregate crime.

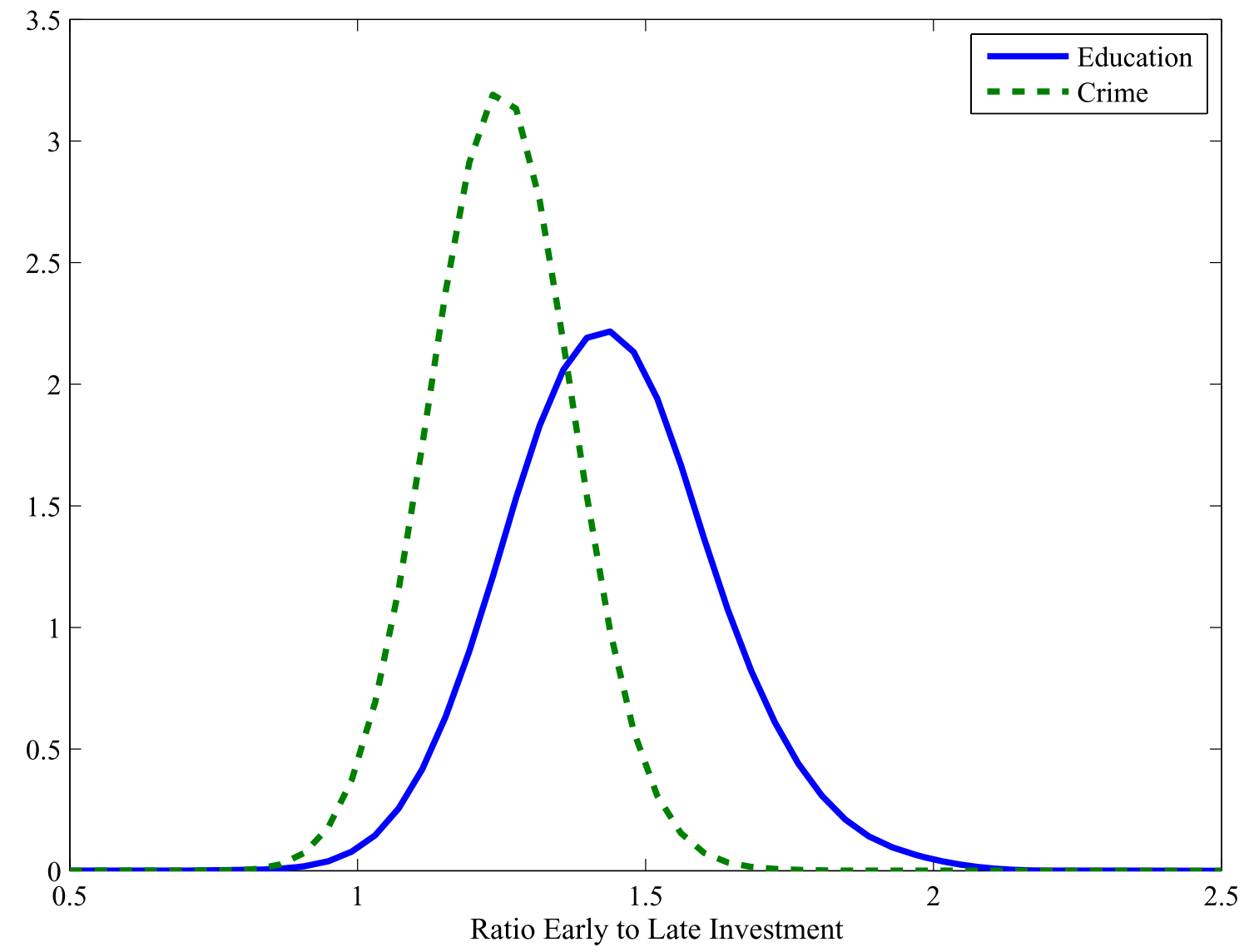

productive. Dynamic complementarity explains why it is productive to invest in the cognitive skills of disadvantaged young children but why the payoffs are so low for cognitive investments in disadvantaged older children and are even lower for disadvantaged adults. There is no equity-efficiency trade-off for investment in the capabilities of young disadvantaged children. There is a substantial equity-efficiency trade-off for investment in the cognitive skills of disadvantaged adolescents and adults. The trade-off is much less dramatic for investment in the noncognitive skills of adolescents. Parental environments and investments affect the outcomes of children. There are substantial costs to uninhibited libertarianism in one generation if the preferences and well-being of the next generation are ignored..$^{41}$

The preferences, motivations, and skill endowments of adults that are created, in part, in their childhoods play important roles in creating inequality. They can be influenced, in part, by policy. But incentives matter too. Society can reduce crime and promote well-being by operating at both incentive and investment margins.

The right mix of intervention to reduce inequality and promote productivity remains to be

\footnotetext{
${ }^{41}$ See Moynihan (2006).
} 
determined. The optimal timing of investment depends on the outcome being targeted. The optimal intervention strategies depend on the stage of the life cycle and endowments at each stage. For severely disadvantaged adults with low levels of capabilities, subsidizing work and welfare may be a better response for alleviating poverty than investment in their skills. The substantial heterogeneity in endowments and effects of interventions at different ages suggests that a universal policy to combat the adverse effects of early disadvantage is not appropriate. Optimal investment should be tailored to the specifics that create adversity and to the productivity of investment for different configurations of disadvantage. As research on the economics of capability formation matures, economists will have a greater understanding of how to foster successful people. 


\section{References}

Aigner, D. J., Hsiao, C., Kapteyn, A., \& Wansbeek, T. (1984). Latent variable models in econometrics. In Z. Griliches, \& M. D. Intriligator (Eds.), Handbook of Econometrics, vol. 2, chap. 23. Amsterdam: Elsevier, pp. 1321-1393.

Aiyagari, S. R., Greenwood, J., \& Seshadri, A. (2002). Efficient investment in children. Journal of Economic Theory, 102(2), 290-321.

Akabayashi, H. (1996). On the role of incentives in the formation of human capital in the family. Ph.D. thesis, University of Chicago. Retrieved from ProQuest Digital Dissertations. (AAT 9629236).

Barnett, W. S. (2004). Benefit-cost analysis of preschool education. URL http://nieer.org/resources/files/BarnettBenefits.ppt, PowerPoint presentation.

Becker, G. S. (1991). A treatise on the family. Cambridge, MA: Harvard University Press, enlarged ed.

Becker, G. S. (1993). Human capital: A theoretical and empirical analysis, with special reference to education. University of Chicago Press, 3rd ed.

Becker, G. S., \& Tomes, N. (1986). Human capital and the rise and fall of families. Journal of Labor Economics, 4(3, Part 2), S1-S39.

Ben-Porath, Y. (1967). The production of human capital and the life cycle of earnings. Journal of Political Economy, 75(4, Part 1), 352-365.

Benabou, R. (2002). Tax and education policy in a heterogeneous agent economy: What levels of redistribution maximize growth and efficiency? Econometrica, $70(2), 481-517$.

Blau, D., \& Currie, J. (2006). Preschool, daycare, and afterschool care: Who's minding the kids? In E. Hanushek, \& F. Welch (Eds.), Handbook of the Economics of Education, Handbooks in Economics, vol. 2, chap. 20. Amsterdam: North-Holland, pp. 1163-1278.

Borghans, L., Duckworth, A. L., Heckman, J. J., \& ter Weel, B. (2008). The economics and psychology of personality traits. Journal of Human Resources, 43(4), 972-1059.

Bowles, S., Gintis, H., \& Osborne, M. (2001). The determinants of earnings: A behavioral approach. Journal of Economic Literature, 39(4), 1137-1176.

Cameron, J. (2004). Evidence for an early sensitive period for the development of brain systems underlying social affiliative behavior. Unpublished manuscript, Oregon National Primate Research Center.

Cameron, S. V., \& Heckman, J. J. (2001). The dynamics of educational attainment for black, hispanic, and white males. Journal of Political Economy, 109(3), 455-99. 
Cameron, S. V., \& Taber, C. (2004). Estimation of educational borrowing constraints using returns to schooling. Journal of Political Economy, 112(1), 132-182.

Carneiro, P., Cunha, F., \& Heckman, J. J. (2003). Interpreting the evidence of family influence on child development. Paper presented at the conference "The Economics of Early Childhood Development: Lessons for Economic Policy," Federal Reserve Bank of Minneapolis, Minneapolis, MN, October 17, 2003.

Carneiro, P., \& Heckman, J. J. (2002). The evidence on credit constraints in post-secondary schooling. Economic Journal, 112(482), 705-734.

Carneiro, P., \& Heckman, J. J. (2003). Human capital policy. In J. J. Heckman, A. B. Krueger, \& B. M. Friedman (Eds.), Inequality in America: What Role for Human Capital Policies? Cambridge, MA: MIT Press, pp. 77-239.

Carneiro, P., Heckman, J. J., \& Vytlacil, E. J. (2006). Estimating marginal and average returns to education. Unpublished manuscript. University of Chicago, Department of Economics.

Caspi, A., McClay, J., Moffitt, T. E., Mill, J., Martin, J., Craig, I. W., et al. (2002). Role of genotype in the cycle of violence in maltreated children. Science, 297(5582), 851-854.

Caucutt, E., \& Lochner, L. J. (2004). Early and late human capital investments, credit constraints, and the family. Unpublished manuscript, University of Western Ontario, Department of Economics.

Center for Human Resource Research (Ed.) (2004). NLSY79 child and young adult data user's guide. Ohio State University, Columbus, Ohio.

Cunha, F., \& Heckman, J. J. (2007). The technology of skill formation. American Economic Review, 97(2), 31-47.

Cunha, F., \& Heckman, J. J. (2008). Formulating, identifying and estimating the technology of cognitive and noncognitive skill formation. Journal of Human Resources, 43(4), 738-782.

Cunha, F., \& Heckman, J. J. (2009). The economics and psychology of inequality and human development. Journal of the European Economic Association, 7(2-3), 320-364. Presented as the Marshall Lecture, European Economics Association, Milan, Italy, August 29, 2008.

Cunha, F., Heckman, J. J., Lochner, L. J., \& Masterov, D. V. (2006). Interpreting the evidence on life cycle skill formation. In E. A. Hanushek, \& F. Welch (Eds.), Handbook of the Economics of Education, chap. 12. Amsterdam: North-Holland, pp. 697-812.

Cunha, F., Heckman, J. J., \& Schennach, S. M. (2010). Estimating the technology of cognitive and noncognitive skill formation. Econometrica, 78(3), 883-931. 
Currie, J., \& Thomas, D. (1995). Does Head Start make a difference? American Economic Review, $85(3), 341-364$.

Currie, J., \& Thomas, D. (2000). School quality and the longer-term effects of Head Start. Journal of Human Resources, 35(4), 755-774.

Dahl, G. B., \& Lochner, L. J. (2005). The impact of family income on child achievement. Working Paper 11279, National Bureau of Economic Research. Manuscript under review, American Economic Review.

Dahl, R. E. (2004). Adolescent brain development: A period of vulnerabilities and opportunities. In R. E. Dahl, \& L. P. Spear (Eds.), Annals of the New York Academy of Sciences. New York: New York Academy of Sciences, pp. 1-22.

Damasio, A. R. (1994). Descartes' error: Emotion, reason, and the human brain. New York: Putnam.

Duncan, G., \& Kalil, A. (2006). The effects of income in the early years on child outcomes. Unpublished manuscript, Northwestern University.

Duncan, G. J., \& Brooks-Gunn, J. (1997). Income effects across the life span: Integration and interpretation. In G. Duncan, \& J. Brooks-Gunn (Eds.), Consequences of Growing Up Poor. New York: Russell Sage Foundation, pp. 596-610.

Duncan, G. J., Dowsett, C. J., Claessens, A., Magnuson, K., Huston, A. C., Klebanov, P., et al. (2007). School readiness and later achievement. Developmental Psychology, 43(6), 1428-1446.

Durbin, J., Harvey, A. C., Koopman, S. J., \& Shephard, N. (2004). State space and unobserved component models: Theory and applications: Proceedings of a conference in honour of James Durbin. New York NY: Cambridge University Press.

Erikson, E. H. (1950). Childhood and society. New York: Norton.

Gluckman, P. D., \& Hanson, M. (2005). The fetal matrix: Evolution, development, and disease. Cambridge, UK: Cambridge University Press.

Hansen, K. T., Heckman, J. J., \& Mullen, K. J. (2004). The effect of schooling and ability on achievement test scores. Journal of Econometrics, 121(1-2), 39-98.

Harvey, A. C. (1989). Forecasting, structural time series models and the Kalman filter. New York: Cambridge University Press.

Heckman, J. J. (1995). Lessons from The Bell Curve. Journal of Political Economy, 103(5), 1091-1120.

Heckman, J. J. (2008). Schools, skills and synapses. Economic Inquiry, 46(3), 289-324. 
Heckman, J. J., Larenas, M. I., \& Urzua, S. (2004). Accounting for the effect of schooling and abilities in the analysis of racial and ethnic disparities in achievement test scores. Unpublished manuscript, University of Chicago, Department of Economics.

Heckman, J. J., Stixrud, J., \& Urzua, S. (2006). The effects of cognitive and noncognitive abilities on labor market outcomes and social behavior. Journal of Labor Economics, 24(3), 411-482.

Herrnstein, R. J., \& Murray, C. A. (1994). The bell curve: Intelligence and class structure in american life. New York: Free Press.

Hopkins, K. D., \& Bracht, G. H. (1975). Ten-year stability of verbal and nonverbal IQ scores. American Educational Research Journal, 12(4), 469-477.

Jöreskog, K. G., \& Goldberger, A. S. (1975). Estimation of a model with multiple indicators and multiple causes of a single latent variable. Journal of the American Statistical Association, 70(351), 631-639.

Knudsen, E. I., Heckman, J. J., Cameron, J., \& Shonkoff, J. P. (2006). Economic, neurobiological, and behavioral perspectives on building America's future workforce. Proceedings of the National Academy of Sciences, 103(27), 10155-10162.

LeDoux, J. E. (1996). The emotional brain: The mysterious underpinnings of emotional life. New York: Simon and Schuster.

Meaney, M. J. (2001). Maternal care, gene expression, and the transmission of individual differences in stress reactivity across generations. Annual Review of Neuroscience, 24(1), 1161-1192.

Meghir, C., \& Palme, M. (2001). The effect of a social experiment in education. Tech. Rep. W01/11, Institute for Fiscal Studies, London, UK.

Moon, S. H. (2010). Multi-dimensional human skill formation with multi-dimensional parental investment. Unpublished manuscript, University of Chicago, Department of Economics.

Morris, P., Duncan, G. J., \& Clark-Kauffman, E. (2005). Child well-being in an era of welfare reform: The sensitivity of transitions in development to policy change. Developmental Psychology, $41(6), 919-932$.

Moynihan, D. P. (2006). The future of the family. New York: Russell Sage Foundation Publications.

Murnane, R. J., Willett, J. B., \& Levy, F. (1995). The growing importance of cognitive skills in wage determination. Review of Economics and Statistics, 77(2), 251-266.

Newport, E. L. (1990). Maturational constraints on language learning. Cognitive Science, 14(1, Special Issue), 11-28. 
O'Connor, T. G., Rutter, M., Beckett, C., Keaveney, L., Kreppner, J. M., \& the English and Romanian Adoptees Study Team (2000). The effects of global severe privation on cognitive competence: Extension and longitudinal follow-up. Child Development, 71 (2), 376-390.

Pinker, S. (1994). The language instinct: How the mind creates language. New York: W. Morrow and Co.

Raudenbush, S. W. (2006). Schooling, statistics and poverty: Measuring school improvement and improving schools. Inaugural Lecture, Division of Social Sciences, University of Chicago.

Raver, C. C., Garner, P. W., \& Smith-Donald, R. (2007). The roles of emotion regulation and emotion knowledge for children's academic readiness: Are the links causal? In R. C. Pianta, M. J. Cox, \& K. L. Snow (Eds.), School Readiness and the Transition to Kindergarten in the Era of Accountability. Baltimore, MD: Brookes Publishing.

Rutter, M. (2006). Genes and behavior: Nature-nurture interplay explained. Oxford, UK: Blackwell Publishers.

Schweinhart, L. J., Montie, J., Xiang, Z., Barnett, W. S., Belfield, C. R., \& Nores, M. (2005). Lifetime effects: The High/Scope Perry Preschool Study through age 40. Ypsilanti, MI: High/Scope Press.

Shonkoff, J. P., \& Phillips, D. (2000). From neurons to neighborhoods: The science of early child development. Washington, DC: National Academy Press.

Stinebrickner, R., \& Stinebrickner, T. (2008). The effect of credit constraints on the college dropout decision: A direct approach using a new panel study. American Economic Review, 98(5), $2163-2184$.

Suomi, S. J. (1999). Developmental trajectories, early experiences, and community consequences: Lessons from studies with rhesus monkeys. In D. P. Keating, \& C. Hertzman (Eds.), Developmental Health and the Wealth of Nations: Social, Biological, and Educational Dynamics. New York: Guilford Press, pp. 185-200.

Weinberg, B. A. (2001). An incentive model of the effect of parental income on children. Journal of Political Economy, 109(2), 266-280. 